\title{
Properties of Lightweight Concrete Blocks with Waste Zeolitic Tuff
}

\section{Ilker TEKIN ${ }^{1}$, Turkay KOTAN ${ }^{2}$, Allison T. OSMANSON ${ }^{3}$, Witold BROSTOW ${ }^{3}$, Osman GENCEL ${ }^{4}$, Gonzalo MARTINEZ-BARRERA ${ }^{5}$}

\author{
${ }^{1}$ Department of Civil Engineering, College of Engineering, Karabük University, Karabük 78000, Turkey \\ ${ }^{2}$ Department of Civil Engineering, College of Engineering, Erzurum Technical University, Erzurum 25000, Turkey \\ ${ }^{3}$ Laboratory of Advanced Polymers \& Optimized Materials (LAPOM), Department of Materials Science and Engineering, \\ University of North Texas, 3940 North Elm Street, Denton TX 76207, USA \\ ${ }^{4}$ Department of Civil Engineering, College of Engineering, Bartin University, Bartin 74100, Turkey \\ ${ }^{5}$ Laboratory of Research and Development of Advanced Materials (LIDMA), Faculty of Chemistry, Autonomous Mexico \\ State University, Km 12 of the Toluca-Atlacomulco highway, San Cayetano 50200, Mexico
}

crossref http://dx.doi.org/10.5755/j01.ms.26.4.22777

\section{Received 13 February 2019; accepted 03 December 2019}

\begin{abstract}
In general, three different types of wall products commonly used in the building sector, namely traditional clay brick, lightweight concrete blocks and aerated concrete, contain pumice and perlite. We have created alternative block walls with Bayburt stone (BS) containing zeolite, namely lightweight concrete masonry blocks (LCMBs). BS was an aggregate, cement dosages ranging from 150 to $250 \mathrm{~kg} / \mathrm{m}^{3}$ were a binder, 3 different type of superplasticizers were selected as a chemical additive. Compressive strength, water absorption, unit weight, elevated heat effect, freeze-thaw resistance, capillary water absorption and thermal conductivity tests were performed. Compressive strength and freeze-thaw resistance of LCMBs are higher than the respective values for the other traditional wall products - with less amount of cement usage. Compressive strength values of lightweight concretes (LCs) were between $4 \mathrm{MPa}$ and $9 \mathrm{MPa}$ on the $3^{\text {rd }}$ day, unit weights of the LCs were between 1.43 and $1.60 \mathrm{~kg} / \mathrm{dm}^{3}$, thermal conductivity values of the so produced block wall elements were $\approx 0.55 \mathrm{~W} / \mathrm{mK}$.

Keywords: lightweight concrete, block wall elements, thermal conductivity, compressive strength, elevated temperature concrete.
\end{abstract}

\section{INTRODUCTION}

The use of lightweight construction materials is very important - especially in earthquake zones. Usage of lightweight materials as partition wall elements is highly preferred in buildings. Unit weights of concretes produced with lightweight aggregates range from 800 to $2000 \mathrm{~kg} / \mathrm{m}^{3}$ [1]. Natural aggregates such as tuff and pumice are volcanic based and their densities varies between 0.65 and $1.85 \mathrm{~g} / \mathrm{cm}^{3}$ due to high porosity [2]. Currently 3 types of elements are used in building partition walls: traditional hollowed clay bricks, aerated concrete and hollowed cement based blocks produced with perlite or pumice. Each of these materials fulfills standards - with different geometrical shapes and predefined properties which differ from country to country. For instance, in Turkey the hollowed clay bricks need a maximum $1.6 \mathrm{~kg} / \mathrm{dm}^{3}$ of unit weight and compressive strength up to $8 \mathrm{MPa}$; cement based hollowed blocks have to have unit weight below $1.6 \mathrm{~kg} / \mathrm{dm}^{3}$ and minimum $2 \mathrm{MPa}$ compressive strength with roughly $400 \mathrm{~kg} / \mathrm{m}^{3}$ dosage; aerated concrete blocks have unit weight below $0.6 \mathrm{~kg} / \mathrm{dm}^{3}$ and minimum $5 \mathrm{MPa}$ compressive strength with $400-550 \mathrm{~kg} / \mathrm{m}^{3}$ dosage cement. Also in Turkey thermal conductivity of all the masonry elements has to be maximally $0.75 \mathrm{~W} / \mathrm{mK}$. Needless to say, there have been around the world various studies aimed at decreasing unit weight and moisture permeability, increasing strength, enhancing radiation shielding capacity and freezing and thawing durability [3-11].

Production of currently used wall elements requires much energy - resulting in extensive $\mathrm{CO}_{2}$ emission and high costs. Turkey has abundance of different types of natural minerals such as hematite, limestone, marble, travertine, onyx, pumice and tuff which was created in volcanic eruptions. In the Bayburt region of Turkey, tuff is called Bayburt Stone (BS). This region has a rich reserve of tuff that is used as capstone with/without being sculpted. During quarry and cutting process, $70 \%$ of the tuff turns into waste. A part of such waste consists of particles called Palladian and also fine particles in the form of sawdust. Needless to say, waste dust is an environmental pollutant.

Recently, irrespective of political, economic or ecological reasons, recycling has been encouraged throughout the world since waste and waste disposal have become a severe social and environmental problem - and that includes making concretes. We need to reduce the impact that the environment can suffer from the consumption of raw materials and the almost random generation of waste [12-17]. Recycling has the potential to reduce the amount of wastes disposed of in landfills and to preserve natural resources. Recycling, one of the strategies in minimizing waste, offers three benefits: (i) reduces the demand for new resources; (ii) cuts down on transport and production energy costs; (iii) utilizes waste which would

\footnotetext{
* Corresponding author. Tel.: (+1)-940-565-3262; fax: (+1)-940-5654824. E-mail address: wkbrostow@gmail.com (W. Brostow)
} 
otherwise go into landfill sites. Concrete containing wastes can support construction sustainability and contribute to the development of the civil engineering area by using industrial waste, lowering the consumption of natural resources and producing more efficient materials.

The purpose of our work was determination of feasibility of using waste tuff in fabrication of lightweight concrete blocks - what involved determination of the effects of waste tuff on properties of lightweight concrete block wall elements.

\section{MATERIALS AND METHODS}

Ordinary Portland cement (OPC) we used as a binder was CEM I 42.5R (OPC) from Askale Cement Factory in Erzurum. Physical and mechanical properties of the OPC are presented in Table 1 and chemical properties in Table 2. The cement content in the mixtures was in a range from 150 to $250 \mathrm{~kg} / \mathrm{m}^{3}$. BS was used as the aggregate.

Table 2. Chemical analysis of OPC and BS (weight \%).

\begin{tabular}{|l|l|l|}
\hline Compound & OPC & BS \\
\hline $\mathrm{SiO}_{2}$ & 18.1 & 68.9 \\
\hline $\mathrm{Al}_{2} \mathrm{O}_{3}$ & 4.6 & 11.9 \\
\hline $\mathrm{Fe}_{2} \mathrm{O}_{3}$ & 2.9 & 0.34 \\
\hline $\mathrm{CaO}$ & 64.5 & 3.85 \\
\hline $\mathrm{MgO}$ & 2.34 & 1.29 \\
\hline $\mathrm{SO}_{3}$ & 2.95 & 0.21 \\
\hline $\mathrm{Na}_{2} \mathrm{O}$ & 0.13 & 0.23 \\
\hline $\mathrm{K}_{2} \mathrm{O}$ & 0.66 & 2.38 \\
\hline $\mathrm{LOI}^{*}$ & 3.31 & 10.1 \\
\hline$*$ Loss on ignition & \\
\hline
\end{tabular}

Three kinds of chemical admixtures were used as plasticizers. The first one was naphthalene sulfonate based ( $\mathrm{N}$ type), the second one was modified sulfonate based ( $\mathrm{M}$ type) and the third one was polycarboxylate based (P type). Properties of those chemical admixtures are given in Table 3.

Mineralogy of Bayburt stone was studied earlier by Tekin [18]. He reported that there are some zeolite crystals such as clinoptilolite and heulandites in BS. Pozzolans are a broad class of siliceous or siliceous and aluminous materials which, in themselves, possess little or no cementitious value but which will, in finely divided form and in the presence of water, react chemically with calcium hydroxide at ordinary temperature to form compounds possessing cementitious properties. The pozzolanic properties of Bayburt stone were studied by Çavdar and Yetgin [19] and they reported compressive strengths ranging from 6.7 to $11 \mathrm{MPa}$.

Waste BS was prepared as aggregate by crushing in a laboratory crusher. In the production of LCs, the Fuller curve was preferred as aggregate gradation. The maximum aggregate size was selected as $8 \mathrm{~mm}$. Particle size distributions of aggregates are given in Table 4.

Specific gravity and water absorption were determined according to the ASTM C127 [20] and ASTM C128 [21] standards. Moreover, compressive strength of white BS was determined as $35 \mathrm{MPa}$ by breaking the cubic samples sized $50 \times 50 \times 50 \mathrm{~mm}$. Physical properties of white BS are listed in Table 5 .

Table 5. Physical properties of white BS

\begin{tabular}{|l|c|c|}
\hline Properties & $\begin{array}{c}0-4 \mathrm{~mm} \\
\text { sieve }\end{array}$ & $\begin{array}{c}4-8 \mathrm{~mm} \\
\text { sieve }\end{array}$ \\
\hline Water absorption, \% & 19.3 & 16.1 \\
\hline Dry specific gravity & 1.65 & 1.61 \\
\hline Specific gravity of saturated and dry surface & 1.96 & 1.86 \\
\hline
\end{tabular}

Fig. 1 shows an image and porosity analysis by using Mercury Intrusion Porosity (MIP) method of the white BS.

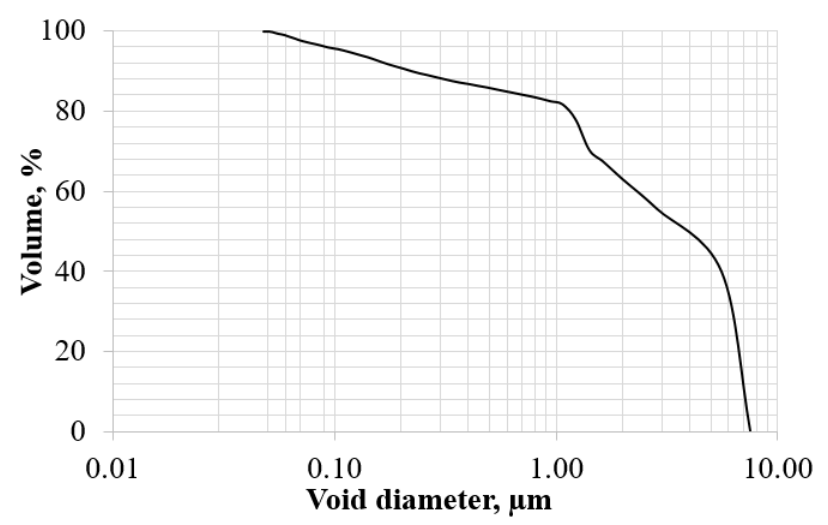

Fig. 1. MIP analysis result of the BSW

In Fig. 1 we see micro and nano pores; their sizes range between $40 \mathrm{~nm}$ and $8 \mu \mathrm{m}$. Moreover, thermal conductivity of the white BS is determined as $\approx 0.58 \mathrm{w} / \mathrm{mK}$ by using the hot plate method.

Table 1. Physical and mechanical properties of OPC

\begin{tabular}{|c|c|c|c|c|c|c|c|c|c|c|}
\hline \multirow{2}{*}{\multicolumn{3}{|c|}{ Compressive strength, MPa }} & \multirow{2}{*}{\multicolumn{3}{|c|}{ Flexural strength, $\mathrm{MPa}$}} & \multicolumn{2}{|c|}{ Setting times, hour } & \multirow{2}{*}{$\begin{array}{c}\text { Soundness, } \\
\mathrm{mm}\end{array}$} & \multirow{2}{*}{$\begin{array}{c}\text { Specific } \\
\text { gravity, } \mathrm{g} / \mathrm{cm}^{3}\end{array}$} & \multirow{2}{*}{$\begin{array}{l}\text { Blaine, } \\
\mathrm{cm}^{2} / \mathrm{g}\end{array}$} \\
\hline & & & & & & Initial & Final & & & \\
\hline $2^{\text {nd }}$ day & $7^{\text {th }}$ day & $28^{\text {th }}$ day & $2^{\text {nd }}$ day & $7^{\text {th }}$ day & $28^{\text {th }}$ day & \multirow{2}{*}{2.24} & \multirow{2}{*}{3.1} & \multirow[b]{2}{*}{1} & \multirow{2}{*}{3.13} & \multirow{2}{*}{3482} \\
\hline 25.9 & 38.6 & 58.2 & 3.8 & 5.7 & 7.2 & & & & & \\
\hline
\end{tabular}

Table 3. Technical properties of chemical admixtures

\begin{tabular}{|l|l|l|l|}
\hline & N type & M type & P type \\
\hline Major component of admixtures & Naphthalene sulfonate based & Modified sulfonate based & Polycarboxylate ether based \\
\hline Color & Brown & Dark brown & Brown \\
\hline $\mathrm{pH}$ & $6.5-8$ & $7-9$ & $5-7$ \\
\hline Density, $\mathrm{kg} / \mathrm{l}$ & $1.15-1.21$ & 1.21 & $1.08-1.14$ \\
\hline Chloride content, \% & $<0.1$ & $<0.1$ & $<0.1$ \\
\hline Alkaline content, \% & $<10$ & $<7$ & $<3$ \\
\hline Ratio of solid content, \% & 35 & 35 & 35 \\
\hline
\end{tabular}


Table 4. Particle size distributions of aggregates

\begin{tabular}{|c|c|c|c|c|c|c|c|c|}
\hline \multirow{3}{*}{ Aggregate type } & \multicolumn{8}{|c|}{ Sieve size } \\
\hline & $9.5 \mathrm{~mm}$ & $4.75 \mathrm{~mm}$ & $2.36 \mathrm{~mm}$ & $1.18 \mathrm{~mm}$ & $600 \mu \mathrm{m}$ & $300 \mu \mathrm{m}$ & $150 \mu \mathrm{m}$ & $75 \mu \mathrm{m}$ \\
\hline & \multicolumn{8}{|c|}{ Percentage passing } \\
\hline$\overline{B S}$ & 100 & 70 & $\overline{50}$ & 35 & 25 & 18 & 12 & 9 \\
\hline
\end{tabular}

White BS is a rock in which its surface has porphyritic texture, and it has quartz and alkali feldspar, and it also contains rich deposits of zeolitic mineral such as clinoptilolite and heulandite (a clay mineral) as found by Tekin using XRD [18]. The w/c ratio was adjusted according to S1 type consistency of the concrete. However, due to the difficulties of compacting of LC type concretes, we tried to find S4 type slump level by trying different plasticizer so that the concrete wall blocks could be produced economic and prefabricate. Thus, each LC mixtures were prepared with 150,200 and $250 \mathrm{~kg} / \mathrm{m}^{3}$ cement. Specimens were produced with different ratios and types of plasticizers. We wanted also to determine compatibility between cement and plasticizer. Firstly, N type plasticizer was used with $1.8 \%, 2 \%, 4 \%, 6 \%, 10 \%$ and $20 \%$ by weight to the cement amount to produce LC type specimens. Secondly, $\mathrm{P}$ type plasticizer and after that $M$ type plasticizer were used. The LC mixtures were prepared by means of the pan type mixer according to mix design presented in Table 6.

While the concrete mixtures were being prepared, initially the water was added to the aggregate in each concrete mix and the combination mixed for $1 \mathrm{~min}$. Following that, mixes were hold in the mixer till aggregates became saturated. When aggregates were being saturated by water, cement was added to the mixture and mixed again for $1 \mathrm{~min}$. Slump test was the first performed and recorded. After that, the prepared fresh concretes were placed into plastic molds, cylindrical shape $\varnothing 10 / 20 \mathrm{~cm}$ sized, in three stages and were compacted on a horizontal vibration table for $1 \mathrm{~min}$. After the samples had been kept $24 \mathrm{~h}$ in the laboratory under a wet cloth, they were taken out from their molds. Then the specimens were placed in a steam curing cabinet at $70^{\circ} \mathrm{C}$ for 7 days as shown in Fig. 2. After LC specimens were taken out from the steam curing cabinet, they were placed in a standard water curing cabinet at $22{ }^{\circ} \mathrm{C}$ till 28th day. After 28 days, specimens were taken out from the curing cabinet and kept in the laboratory condition at
$20 \pm 2{ }^{\circ} \mathrm{C}$ and $50 \pm 5 \%$ relative humidity (R.H.). The compressive strength tests were performed on three samples on $3^{\text {rd }}, 7^{\text {th }}, 28^{\text {th }}, 90^{\text {th }}$ and $1800^{\text {th }}$ day. Scanning electron microscopy observations were performed with FEI Nova Nano SEM 450 on $28^{\text {th }}$ day. Water absorption tests were performed on $90^{\text {th }}$ day.

In the last stage, the best specimen were selected for final tests such as freeze-thaw resistance, thermal conductivity, elevated temperature effect, capillary action and toughness calculation. A group of LC14 specimens was selected on the basis of a high compressive strength on $3^{\text {rd }}$ day, low chemical admixture level with $250 \mathrm{~kg} / \mathrm{m}^{3}$ cement and good workability. Freeze-thaw resistance testing was performed according to the ASTM C666 standard [22]. Cubic specimens with the sizes of $10 \times 10 \times 10 \mathrm{~cm}$ were prepared for elevated heat exposure tests, and prismatic specimens with the sizes of $10 \times 10 \times 40 \mathrm{~cm}$ were prepared for capillary action testing according to the mixture design of the LC14 type concrete. Thermal conductivity tests were performed according to the hot plate method developed by Soroka and coworkers [23] on specimens sized of $1 \times 2 \times 4 \mathrm{~cm}$ from the LC14 type mixture. Elevated heat exposure tests were performed on the LC14 type concrete specimens at $100{ }^{\circ} \mathrm{C}, 300{ }^{\circ} \mathrm{C}, 500{ }^{\circ} \mathrm{C}$ and $700{ }^{\circ} \mathrm{C}$ on $7^{\text {th }}$ day. During the heat exposure tests, the specimens were kept in a furnace for 2 hours after the predefined temperature was achieved, and then until the room temperature was reached by natural cooling. Compressive strength tests were done on all LC14 specimens after heat exposure. Strain-stress measurements were performed under compression. Moreover, Excel software was used to look for a relation between strain-stress and thermal results. The areas under the curves were calculated with the help of AutoCAD software to calculate toughness values.

Capillary absorption tests were performed according to ASTM C1585 [24], on LCWB samples with size of $10 \times 10 \times 40 \mathrm{~m}$ in a stand shown in Fig. 2 .

Table 6. Mixture proportions

\begin{tabular}{|l|c|c|c|c|c|c|c|c|c|}
\hline Code & $\begin{array}{c}\text { Cement, } \\
\mathrm{kg} / \mathrm{m}^{3}\end{array}$ & $\begin{array}{c}\mathrm{BT} 0-4, \\
\mathrm{~kg} / \mathrm{m}^{3}\end{array}$ & $\begin{array}{c}\mathrm{BT} 4-8, \\
\mathrm{~kg} / \mathrm{m}^{3}\end{array}$ & $\begin{array}{c}\text { Water, } \\
\mathrm{kg} / \mathrm{m}^{3}\end{array}$ & W/C & W/B & $\begin{array}{c}\text { Plasticizer } \\
\text { type }\end{array}$ & $\begin{array}{c}\text { Plasticizer } \\
\text { ratio, } \%\end{array}$ & $\begin{array}{c}\text { Air-entraining } \\
\text { admixture, } \%\end{array}$ \\
\hline LC1 & 150 & 584 & 831 & 207 & 1.38 & 1.00 & $\mathrm{~N}$ & 1.8 & - \\
\hline LC2 & 150 & 573 & 816 & 205 & 1.37 & 0.99 & $\mathrm{~N}$ & 2.0 & - \\
\hline LC3 & 150 & 576 & 820 & 202 & 1.35 & 0.97 & $\mathrm{~N}$ & 4.0 & - \\
\hline LC4 & 150 & 578 & 823 & 199 & 1.33 & 0.96 & $\mathrm{~N}$ & 6.0 & - \\
\hline LC5 & 150 & 584 & 831 & 192 & 1.28 & 0.92 & $\mathrm{~N}$ & 10 & - \\
\hline LC6 & 150 & 625 & 890 & 139 & 0.93 & 0.66 & $\mathrm{~N}$ & 20 & - \\
\hline LC7 & 150 & 590 & 840 & 184 & 1.23 & 0.88 & $\mathrm{P}$ & 2.5 & - \\
\hline LC8 & 150 & 638 & 908 & 123 & 0.82 & 0.57 & $\mathrm{P}$ & 4.0 & - \\
\hline LC9 & 150 & 599 & 853 & 172 & 1.15 & 0.82 & $\mathrm{M}$ & 2.5 & - \\
\hline LC10 & 150 & 622 & 887 & 142 & 0.95 & 0.67 & $\mathrm{M}$ & 2.5 & - \\
\hline LC11 & 200 & 595 & 847 & 162 & 0.81 & 0.62 & $\mathrm{M}$ & 2.5 & 0.5 \\
\hline LC12 & 200 & 595 & 847 & 162 & 0.81 & 0.62 & $\mathrm{M}$ & 2.5 & 0.5 \\
\hline LC13 & 250 & 551 & 784 & 202 & 0.81 & 0.66 & $\mathrm{M}$ & 2.5 & 1.0 \\
\hline LC14 & 250 & 551 & 784 & 202 & 0.81 & 0.66 & $\mathrm{M}$ & 2.5 & 0.5 \\
\hline
\end{tabular}




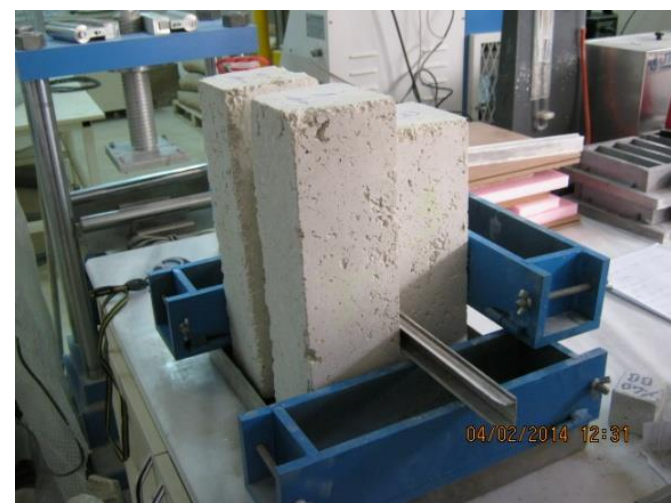

Fig. 2. Capillary absorption testing stand

\section{RESULTS AND DISCUSSION}

The testing results are summarized in Table 7 and also in Fig. 3 and Fig. 4.

As can be seen in Table 7, for the specimens with $\mathrm{N}$ type plasticizer, with increasing pasticizer concentration the compressive strength increases. However, the increases between $3^{\text {rd }}$ to $90^{\text {th }}$ days are not that significant for $\mathrm{LC} 1-\mathrm{LC} 4$, this due to the lower cement dosage.

Steam curing is known to be important in the concrete technology. Especially, if pozzolanic material is used in a concrete along with steam curing between 60 to $80{ }^{\circ} \mathrm{C}$, the concrete compressive strength can reach on $7^{\text {th }}$ day $90 \%$ of its value on $28^{\text {th }}$ day [25]. Compressive strength values of the $\mathrm{LC} 11-\mathrm{LC} 14$ (200 and $250 \mathrm{~kg} / \mathrm{m}^{3}$ cement) increased $20-50 \%$ on $90^{\text {th }}$ day with respect to the $7^{\text {th }}$ day.

In Fig. 3 we show the dependence of the compressive strength on the admixture ratio. According to Fig. 3, there is a strong correlation between the plasticizer ratio and the compressive strength. However, using chemical admixture in $20 \%$ ratio is too high; there is a negative effect on setting time and cost. Moreover, $\mathrm{N}$ type plasticizer did not reduce the w/c ratios sufficiently for the same workability in the LC1-LC6 group because of lower cement dosages. Therefore, when the cement dosages in LCs were below $150 \mathrm{~kg} / \mathrm{m}^{3}$, the plasticizer effects on the properties of LC1 - LC6 were relatively small.

Table 7. Test results
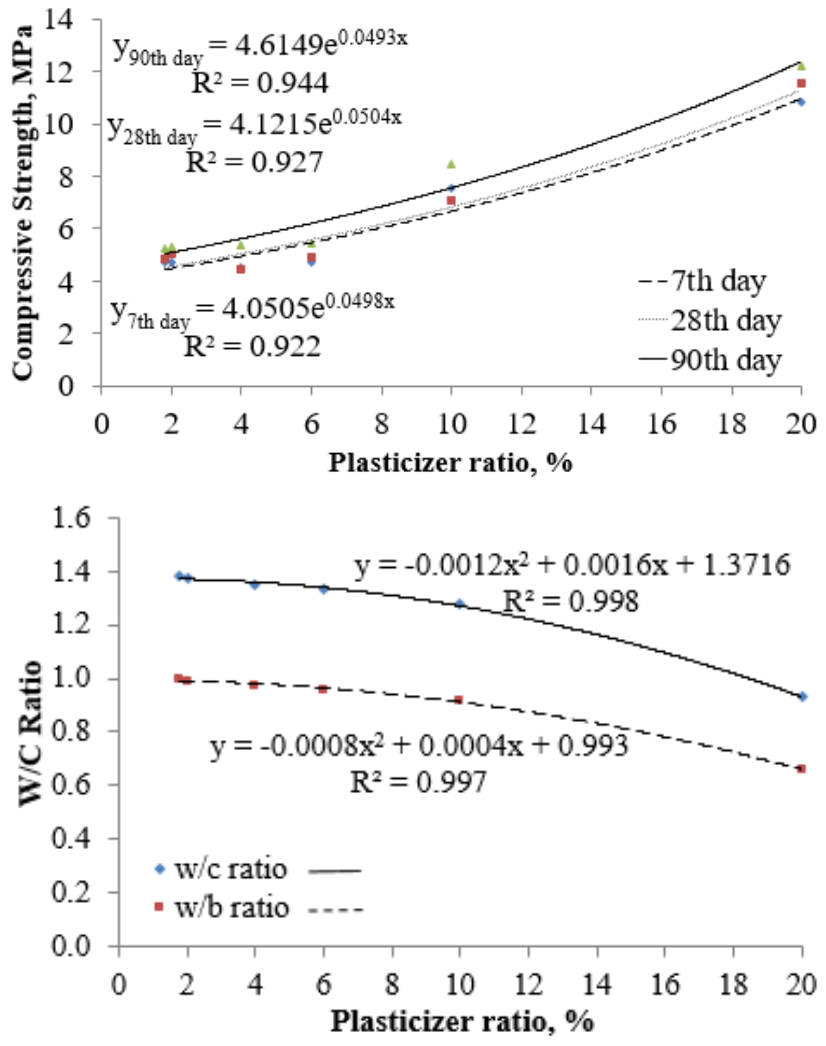

Fig. 3. a-relation between compressive strength and admixture ratio of LC1 to LC6; b-relation between w/c ratio and admixture ratio for $\mathrm{LC} 1$ to $\mathrm{LC} 6$

We see in Fig. 4 that the water absorption values for LCs $1-8$ are between 10 and $18 \%$ because of low workability of LCs. The compressive strength values are related to the water absorption values. Unit weights and water absorption ratios for the LCs are also listed in Table 7. The unit weights are between 1.43 and $1.60 \mathrm{~kg} / \mathrm{dm}^{3}$. Apparently water absorption and unit weights decrease as the admixture ratios increase for the LC1 - LC6, this due to relatively low w/c ratios. The increases in the admixture ratio do not change the unit weights of hardened concrete significantly.

\begin{tabular}{|l|c|c|c|c|c|c|c|c|c|c|}
\hline \multirow{2}{*}{ Code } & \multirow{2}{*}{$\begin{array}{c}\text { Cement } \\
\mathrm{kg} / \mathrm{m}^{3}\end{array}$} & \multirow{2}{*}{$\begin{array}{c}\mathrm{SP} \\
\text { type }\end{array}$} & \multirow{2}{*}{$\begin{array}{c}\text { Slump, } \\
\mathrm{cm}\end{array}$} & $\begin{array}{c}\text { Unit weight, } \\
\mathrm{kg} / \mathrm{dm}^{3}\end{array}$ & $\begin{array}{c}\text { Water } \\
\text { absorption, on } \\
90^{\text {th }} \text { day }\end{array}$ & $\begin{array}{c}3^{\text {rd }} \\
\text { day }\end{array}$ & $7^{\text {th }}$ day & $28^{\text {th }}$ day & $\begin{array}{c}\text { Average compressive strengths, MPa } \\
90^{\text {th }} \text { day }\end{array}$ & $\begin{array}{c}1800^{\text {th }} \\
\text { day }\end{array}$ \\
\hline LC1 & 150 & $\mathrm{~N}$ & 3 & 1.49 & 0.18 & 4.1 & 4.7 & 4.9 & 5.2 & 7.2 \\
\hline LC2 & 150 & $\mathrm{~N}$ & 4 & 1.47 & 0.17 & 4.2 & 4.7 & 5.1 & 5.3 & 8 \\
\hline LC3 & 150 & $\mathrm{~N}$ & 4 & 1.46 & 0.17 & 4 & 4.5 & 4.5 & 5.3 & 8.9 \\
\hline LC4 & 150 & $\mathrm{~N}$ & 3 & 1.50 & 0.16 & 4.4 & 4.7 & 5 & 5.5 & 8.5 \\
\hline LC5 & 150 & $\mathrm{~N}$ & 4 & 1.50 & 0.15 & 6.9 & 7.5 & 7.1 & 8.4 & 12.1 \\
\hline LC6 & 150 & $\mathrm{~N}$ & 4 & 1.55 & 0.11 & 8.4 & 10.8 & 11.6 & 12.2 & 18.2 \\
\hline LC7 & 150 & $\mathrm{P}$ & 4 & 1.58 & 0.12 & 3.9 & 4.1 & 4.9 & 5.1 & 7.7 \\
\hline LC8 & 150 & $\mathrm{P}$ & 4 & 1.60 & 0.11 & 3.9 & 4.1 & 4.5 & 5 & 6.5 \\
\hline LC9 & 150 & $\mathrm{M}$ & 4 & 1.59 & 0.12 & 4.5 & 4.8 & 5.2 & 5.6 & 7.7 \\
\hline LC10 & 150 & $\mathrm{M}$ & 4 & 1.54 & 0.10 & 5.2 & 5.4 & 5.8 & 6.1 & 9.4 \\
\hline LC11 & 200 & $\mathrm{M}$ & 4 & 1.44 & 0.11 & 5.1 & 5.8 & 6.1 & 6.4 & 10 \\
\hline LC12 & 200 & $\mathrm{M}$ & 7 & 1.43 & 0.13 & 5 & 5.2 & 5.8 & 6.2 & 10.6 \\
\hline LC13 & 250 & $\mathrm{M}$ & 8 & 1.52 & 0.10 & 6.6 & 7.4 & 8.3 & 9 & 14.3 \\
\hline LC14 & 250 & $\mathrm{M}$ & 19 & 1.46 & 0.12 & 8.9 & 10.9 & 12.4 & 13.3 & 21.4 \\
\hline
\end{tabular}




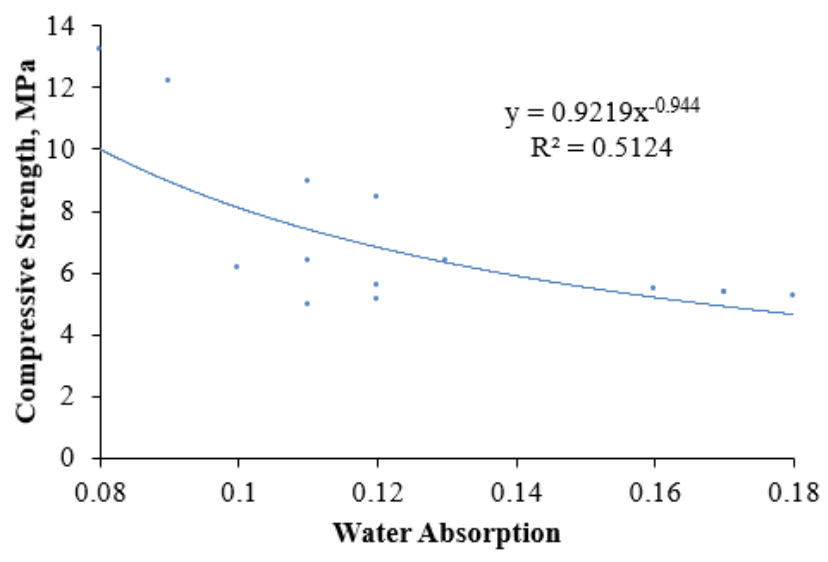

Fig. 4. Relations between compressive strength test results and water absorption of LC's

The water demand of fresh LC type concretes decreases as the quantity of admixture increases. However, as also seen in Table 7 , the decreases vary with changing the plasticizer ratio. In LC1 to LC6 specimens, when the ratio of admixture was increased from $10 \%$ to $20 \%$, the w/c and w/b ratios decreased by $35 \%$ and $26 \%$, respectively. This can be explained by the existence of an enhanced interface zone between cement and aggregates at lower w/c ratios. We also note that the maximum calcium silicate hydrate (CSH) bonding structure can be formed by rapid steam curing [1]. As shown in Table 7, minimum requirements for compressive strength and unit weight are fulfilled by the LC5, LC6, LC13 and LC14 types of concretes according to the specification of wall elements. However, LC5 and LC6 have high plasticizer ratio and are not cost effective. LC13 is good choice for producing LCWB elements, but workability is lesser than for the LC14 type mix design. Therefore, LC14 mix design was selected as optimal for production for LCWB elements. The elements were manufactured as shown in Fig. 5.

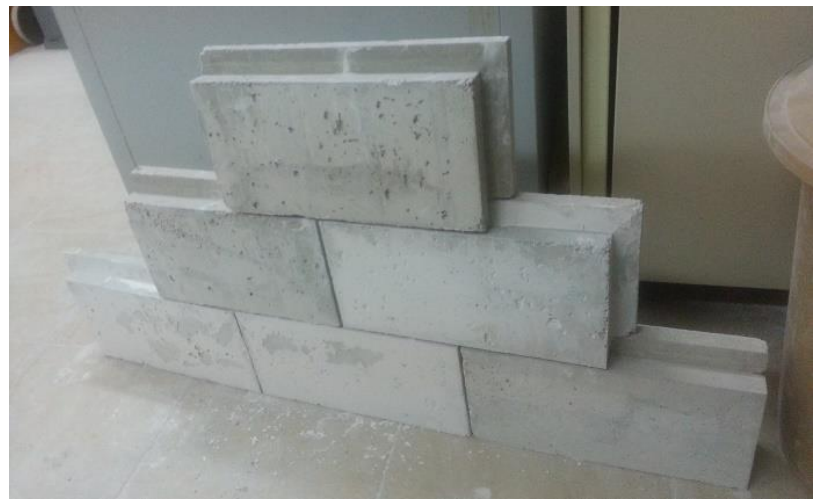

Fig. 5. LC block wall elements produced from mix design of LC14 type concrete

Microscopic observations of LC14 type concrete are shown in Fig. 6.
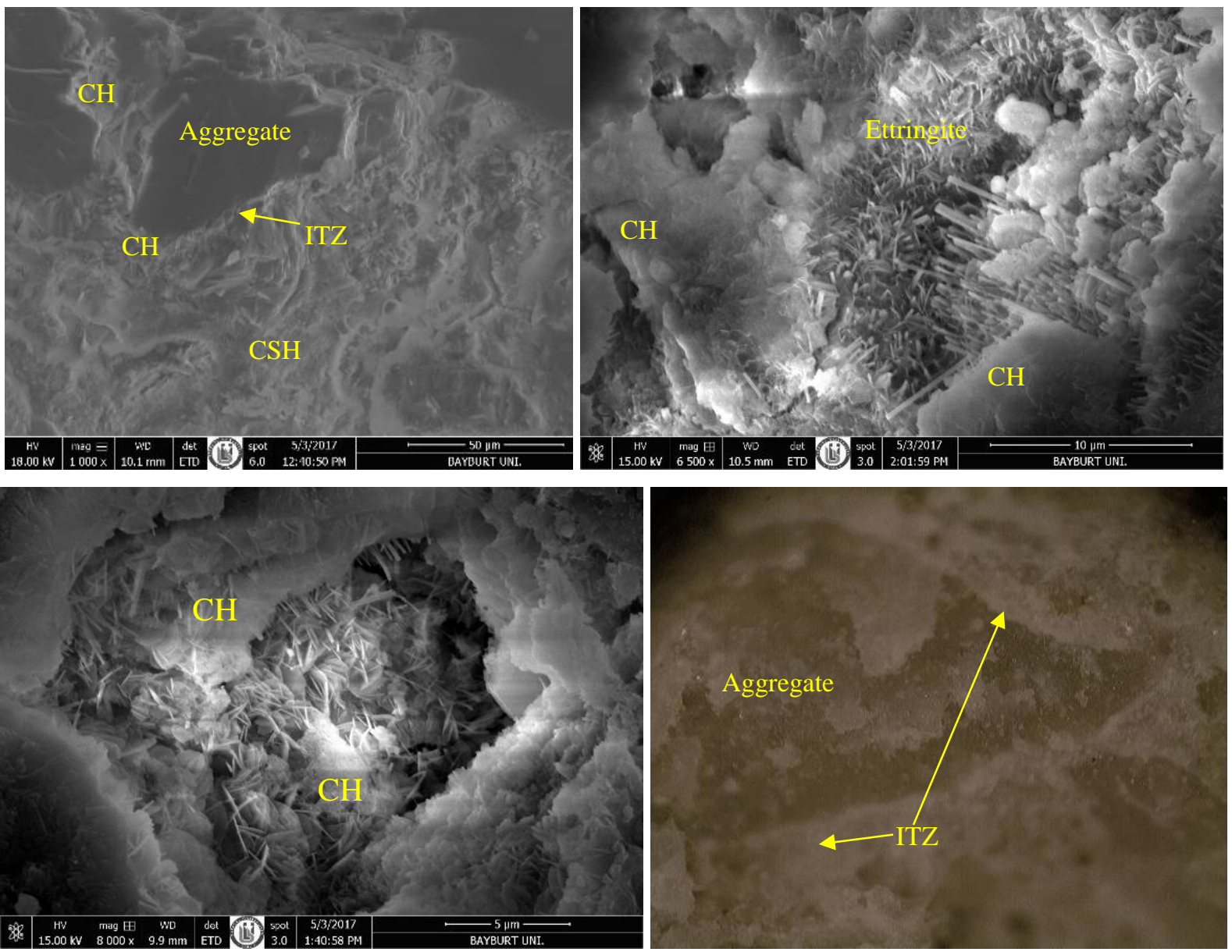

Fig. 6. SEM and optical microscope images of LC14 type concrete on $28^{\text {th }}$ day; $\mathrm{CH}$ is calcium hydroxide, ITZ is the interfacial transition zone 
According to Fig. 6, there are large amounts of calcium hydroxide $(\mathrm{CH})$ particles on surfaces and in voids of LC14 type concrete. Dense ettringite and $\mathrm{CH}$ structures can be also seen on $28^{\text {th }}$ day. Thus, the pozzolanic activity of BS did not produce large effects on $28^{\text {th }}$ day. However, compressive strength gain continued due to that activity of BS. LC14 type concrete gained compressive strength roughly $61 \%$ in 5 years. Moreover, compressive strength of the other type concretes increases between $40 \%-60 \%$ in 5 years. Because CEM I type cement from Askale Cement factory we have used has $70 \%$ ratio of $\mathrm{C}_{3} \mathrm{~S}$ according to Bogue formula, large numbers of $\mathrm{CH}$ particles are made up by the hydration process. Those particles increase the pozzolanic activity of BS, hence an increase in compressive strength.

Capillary absorption test results for the LC14 type concrete according to the ASTM C1585 are shown in Fig. 7. In that Figure "I" is the capillary absorption value which changes with time. To calculate the absorption value from the test, when the point of slope change, $\mathrm{m}_{\mathrm{t}}$ (the change in specimen mass in grams, at the time t), a (the exposed area of the specimen, in $\mathrm{mm}^{2}$ ) and $\mathrm{d}$ (the density of the water in $\mathrm{g} / \mathrm{mm}^{3}$ ) values are recorded, and then the absorption can be calculated [29] as:

$I=m_{\mathrm{t}} /(a \times d)$.

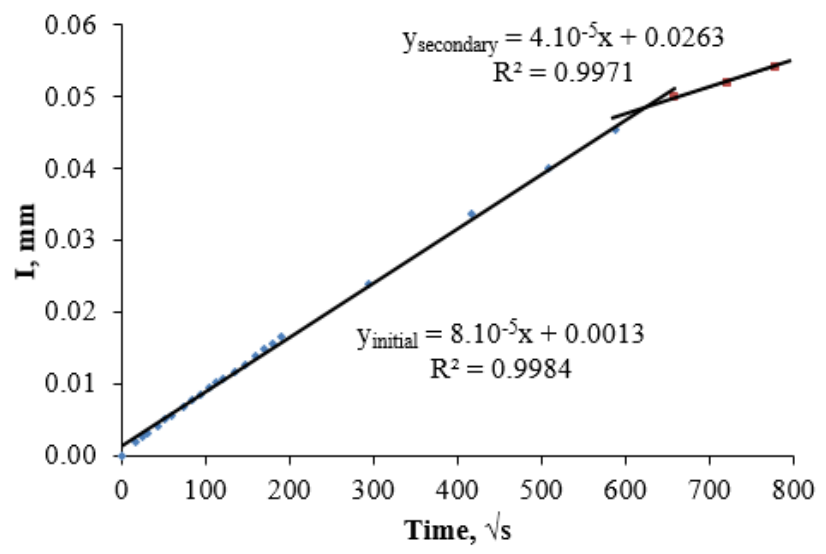

Fig. 7. Diagram of capillary absorption rate for the LC14 type LCWB

Initial capillary absorption (sorptivity) rate and secondary absorption rate for the LC14 type concrete are $8.30 \times 10^{-5}$ and $5.82 \times 10^{-5}$, respectively. Capillary voids are more active in this respect in the initial phase due to their small diameter. Therefore, there is a change of slope point and the slope to the right of that point is lower than slope of the initial capillary absorption. According to these results, capillary absorption rate of the LC14 type concrete was 10 times higher than in the conventional structural concretes with $0.38-0.42 \mathrm{w} / \mathrm{c}$ ratio [23].
Slump behavior of LC14 type concrete specimens was observed as plastic - even at high level w/c ratios - due to the high cohesion of white BS. Therefore, $81 \% \mathrm{w} / \mathrm{c}$ ratio was used for preparing the LC14 concrete specimens with $19 \mathrm{~cm}$ slump, while the compressive strength on $3^{\text {rd }}$ day was obtained as $8 \mathrm{MPa}$ with the help of hot steam curing. The results of thermal conductivity tests on LC14 type concrete are given in Table 8 .

The average thermal conductivity value for the samples listed in Table 8 is $0.55 \mathrm{~W} / \mathrm{mK}$. The standard requires values below $0.75 \mathrm{~W} / \mathrm{mK}$.

Compressive testing results of LC14 type LCWB are presented in Fig. 8 as stress vs. strain values for several temperatures, after heat exposures at $100{ }^{\circ} \mathrm{C}$, $300{ }^{\circ} \mathrm{C}, 500^{\circ} \mathrm{C}$ and $700{ }^{\circ} \mathrm{C}$.

Table 8. Heat transfer parametr values of the wall elements

\begin{tabular}{|c|c|}
\hline Code & W/mK \\
\hline LC14_1 & 0.549 \\
\hline LC14_2 & 0.553 \\
\hline LC14_3 & 0.550 \\
\hline LC14_4 & 0.551 \\
\hline LC14_5 & 0.548 \\
\hline LC14_6 & 0.549 \\
\hline Average value & 0.550 \\
\hline Standard deviation & 0.0018 \\
\hline
\end{tabular}

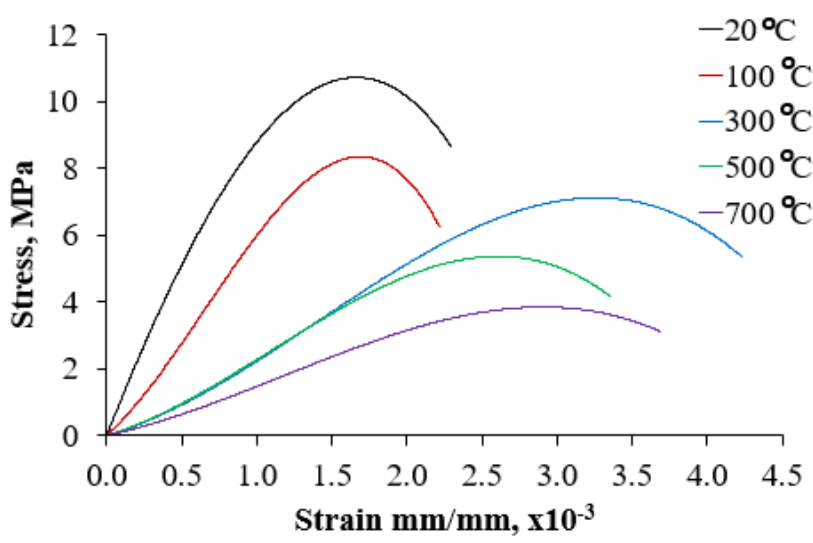

Fig. 8. Effect of elevated temperature on stress-strain relationship of LC14 type wall element in compressive testing

There are several definitions of toughness, but the most often used is: the surface area under the stress vs. strain diagram $[28,26]$. Toughness values of the LC14 type specimen were calculated from stress-strain curves. The compressive strength, compressive modulus and compressive toughness values of the LCWB elements are provided in Table 9.

Table 9. Compressive properties of block element exposed to elevated temperature

\begin{tabular}{|c|c|c|c|c|c|c|c|}
\hline \multirow{2}{*}{ Temperature, ${ }^{\circ} \mathrm{C}$} & \multirow{2}{*}{$\begin{array}{c}\text { Compressive } \\
\text { strength, MPa }\end{array}$} & \multirow{2}{*}{$\begin{array}{c}\text { Young's } \\
\text { modulus, GPa }\end{array}$} & $\begin{array}{c}\text { Compressive toughness } \\
\text { index, } \mathrm{W}_{\mathrm{cu}}\end{array}$ & \multicolumn{4}{|c|}{ Stress - strain properties } \\
\cline { 5 - 8 } & 10.9 & 7.91 & 42.02 & 2.76 & 1.52 & 1.65 & 10.9 \\
\hline 20 & 6.93 & 49.41 & 1.87 & 1.02 & 1.70 & 8.35 \\
\hline 100 & 8.4 & 6.39 & 50.83 & 3.02 & 1.52 & 3.25 & 7.10 \\
\hline 300 & 7.1 & 5.57 & 51.24 & 1.83 & 0.91 & 2.60 & 5.40 \\
\hline 500 & 5.4 & 4.71 & 50.78 & 1.47 & 0.70 & 2.90 & 3.85 \\
\hline 700 & 3.8 & \multicolumn{5}{c}{$\mathrm{A}_{1} \times 10^{-3}$} & $f_{\mathrm{c}}$ \\
\hline
\end{tabular}


$\mathrm{A}_{1}$ values in $\mathrm{MPa}$ are the areas until the first crack point on the stress-strain curves. $\mathrm{A}_{2}$ values also in $\mathrm{MPa}$ are the areas between the first crack point and the end point on the same curves. $\varepsilon_{\mathrm{c}}$ values are deformations corresponding to the maximum compressive strengths while $f_{\mathrm{c}}$ are the peak points corresponding to those maxima. Compressive toughness index $\mathrm{W}_{\mathrm{cu}}$ values are calculated [29] as

$W_{c u}=\frac{\Omega}{A \cdot l}$,

where $\Omega_{\mathrm{u}}$ is the area under the load-deformation curve with the vertical deformation in N.mm; $A$ is the area of the specimen subjected to uniaxial compression while $l$ is the specimen height.

Young moduli of the LCWB elements were calculated according to the ACI 318 standard [27]. As it can be seen in Table 9, compressive strength and compressive Young modulus values decrease with heat exposure. The compressive toughness $\mathrm{W}_{\mathrm{cu}}$ is higher at elevated temperature than at $20^{\circ} \mathrm{C}$ - while its values do not change significantly between 100 and $700{ }^{\circ} \mathrm{C}$. Possibly raising the temperature to $100{ }^{\circ} \mathrm{C}$ increases the ductility significantly while further temperature increases have only small effects.

\section{CONCLUSIONS}

The ZT can be used as an aggregate and pozzolanic material in LWCB with low cement content. Although $150 \mathrm{~kg} / \mathrm{m}^{3}$ can be enough for producing LWCB, consistency was not sufficient for industrial manufacturing. Lower cement content about $150 \mathrm{~kg} / \mathrm{m}^{3}$ is not convenient to produce LWCB due to freeze-thaw resistance. Minimum cement content was observed as $250 \mathrm{~kg} / \mathrm{m}^{3}$. Compressive strength of LWCB achieved to $8.9 \mathrm{MPa}$ and $21.4 \mathrm{MPa}$ at $3^{\text {rd }}$ and $1800^{\text {th }}$ days, respectively. Compressive strength is sufficient for the structural wall elements in the size of $10 \times 20 \times 40 \mathrm{~cm}$. With that size, LWCB formed as $11.68 \mathrm{~kg}$, and if desired, the product can be formed with holes and the weight of its can be reduced by this method. LWCB is also durable for heat exposure till $700^{\circ} \mathrm{C}$ and its toughness is very good for a block wall element. Freeze-thaw resistance of the LWCB is good enough for structural wall elements as well. Thermal conductivity of the LWCB element provide sufficient value for the wall elements. When it comes to the cost of LWCB, it is better than an aerated concrete and a masonry hollow blocks; however, it is expensive for clay hollowed brick. Nevertheless, casualty rate of LWCB is lower than the clay brick. With this study, the new LWCB was produced by different process and some of way of its were better than the others.

\section{REFERENCES}

1. Mehta, P.K., Monteiro, P.J.M. Concrete: Microstructure, Properties and Materials, 3rd Edition, McGraw Hill, New York, 2006: pp. 704.

2. Clarke, J.L. Structural Concrete with Lightweight Aggregate, Blackie Academic \& Professional, Glasgow, 2005: pp. 282.
3. Gencel, O., Brostow, W., Ozel, C., Filiz, M. Concretes Containing Hematite for Use as Shielding Barriers Materials Science (Medžiagotyra) 16 (3) 2010: pp. 249-256.

4. Gencel, O., Ozel, C., Koksal, F., Martinez-Barrera, G., Brostow, W., Polat, H. Fuzzy Logic Model for Prediction of Properties of Fiber-Reinforced Self-Compacting Concrete Materials Science (Medžiagotyra) $19(2)$ 2013: pp. $203-215$. https://doi.org/10.5755/j01.ms.19.2.4439

5. Gencel, O., del Coz Diaz, J.J., Sutcu, M., Koksal, F., Álvarez Rabanal, F.P., $\quad$ Martinez Barrera, G., Brostow, W. Properties of Gypsum Composites Containing Vermiculite and Polypropylene Fibers: Numerical and Experimental Results Energy and Buildings 70 2014: pp. $135-144$. https://doi.org/10.1016/j.enbuild.2013.11.047

6. Brostow, W., Chetuya, N., Hnatchuk, N., Uygunoglu, T. Reinforcing Concrete: Comparison of filler effects Journal of Cleaner Production 112 2016: pp. 2243. https://doi.org/10.1016/j.jclepro.2015.09.105

7. Gao, F., Guo, Y., Yuan, H., Fan, C., Li, K. The Investigation on Flexural Toughness of Partially Steel Fiber Reinforced Concrete Immersed in Simulated Sea-Water Materials Science (Medžiagotyra) 23 (4) 2017: pp. $372-377$ http://dx.doi.org/10.5755/j01.ms.23.4.17049

8. Gunasekaran, M., Thangavel, M., Nemichandran, N.C., Ravikumar, I., Glarance, H.J., Kothandapani. K. Impact Response and Strength Reliability of Green High Performance Fibre Reinforced Concrete Subjected to Freezethaw Cycles in $\mathrm{NaCl}$ Solution Materials Science (Medžiagotyra) 23 (4) 2017: pp. 384-388. http://dx.doi.org/10. 5755/j01.ms.23.4.17334

9. Beycioglu, A., Gencel, O., Aruntas, H.Y., Brostow, W., Hagg Lobland, H.E. Effect of Elevated Temperatures on Properties of Blended Cements with Clinoptilolite Materials Science (Medžiagotyra) 22 (4) 2016: pp. 548-552. http://dx.doi.org/10.5755/j01.ms.22.4.13354

10. Levinskas, R., Lukosiute, I., Baltusnikas, A., Kuoga, A., Luobikiene, A., Rodriguez, J., Cañadas, I., Brostow, W. Modified Xonotlite-type Calcium Silicate Hydrate Slabs for Fire Doors Journal of Fire Sciences 36 2018: pp. 83-96. https://doi.org/10.1177/0734904118754381

11. Amini, F., Barkhordari Bafghi, M.A., Safayenikoo, H., Sarkardeh, H. Strength of Different Fiber Reinforced Concrete in Marine Environment Materials Science (Medziagotyra) 24 (2) 2018: pp. 204-211. http://dx.doi.org/10.5755/j01.ms.24.2.17909

12. Pelisser, F., Zavarise, N., Longo, T.A., Bernardin, A.M. Concrete Made with Recycled Tire Rubber: Effect of Alkaline Activation and Silica Fume Addition Journal of Cleaner Production 19 (6-7) 2011: pp. 757-763. https://doi.org/10.1016/j.jclepro.2010.11.014

13. Correia, J.R., Almeida, N.M., Figueira, J.R. Recycling of FRP Composites: Reusing Fine GFRP Waste in Concrete Mixtures Journal of Cleaner Production 19 (15) 2011: pp. $1745-1753$. https://doi.org/10.1016/j.jclepro.2011.05.018

14. Gencel, O., Ozel, C. Koksal, F., Erdogmus, E., MartínezBarrera, G., Brostow, W. Properties of Concrete Paving Blocks Made with Waste Marble Journal of Cleaner Production 21 2012: pp. 62-70. https://doi.org/10.1016/j.jclepro.2011.08.023 
15. Dobiszewska, M. Waste Materials Used in Making Mortar and Concrete Journal of Materials Education 39 2017: pp. $133-156$.

16. Namarak, C., Bumrungsri, C., $\quad$ Tangchirapat, W., Jaturapitakkul, C. Development of Concrete Paving Blocks Prepared from Waste Materials without Portland Cement Materials Science (Medžiagotyra) 24 (1) 2018: pp. 92-99. http://dx.doi.org/10.5755/j01.ms.24.1.17566

17. Brostow, W., Chetuya, N., Gencel, O., Sayana, S. Durability of Portland Concrete Containing Polymeric Fillers and Fly Ash Materials Science (Medžiagotyra) 26 (1) 2020: pp. $103-108$. https://doi.org/10.5755/j01.ms.26.1.21367

18. Tekin, I. Properties of $\mathrm{NaOH}$ Activated Geopolymer with Marble, Travertine and Volcanic Tuff Wastes Construction and Building Materials 127 2016: pp. 607-617. https://doi.org/10.1016/j.conbuildmat.2016.10.038

19. Çavdar, A., Yetgin, Ş. Availability of Tuffs from Northeast of Turkey as Natural Pozzolan on Cement, Some Chemical and Mechanical Relationships Construction and Building Materials 21 2007: pp. 2066-2071. https://doi.org/10.1016/j.conbuildmat.2006.05.034

20. ASTM C127-15, Standard Test Method for Relative Density (Specific Gravity) and Absorption of Coarse Aggregate, ASTM International, West Conshohocken, PA, 2015.

21. ASTM C128-15, Standard Test Method for Relative Density (Specific Gravity) and Absorption of Fine Aggregate, ASTM International, West Conshohocken, PA, USA 2015.
22. ASTM C666, Standard Test Method for Resistance of Concrete to Rapid Freezing and Thawing, ASTM International, West Conshohocken, PA, USA 2015.

23. Soroka, I., Jaegermann, C.H., Bentur, A. Short-term Steam-curing and Concrete Later-age Strength Materials and Structures 11 (2) 1978: pp. 93-96. https://doi.org/10.1007/BF02478955

24. ASTM C1585-13, Standard Test Method for Measurement of Rate of Absorption of Water by Hydraulic-Cement Concretes, ASTM International, West Conshohocken, PA, USA 2015.

25. Mohammadi, B. Development of Concrete Water Absorption Testing for Quality Control. A Master Thesis in The Department of Building, Civil, and Environmental Engineering, Concordia University, Montreal, Quebec, Canada, 2013, 123 pages.

26. Brostow, W., Hagg Lobland, H.E. Materials: Introduction and Applications. John Wiley \& Sons 2017.

27. ACI 318, Building Code Requirements for Structural Concrete, Reported by ACI Committee 318, American Concrete Institute 2014.

28. Brostow, W., Hagg Lobland, H.E., Khoja, S. Brittleness and Toughness of Polymers and other Materials Materials Letters 159 2015: pp. 478-480. https://doi.org/10.1016/j.matlet.2015.07.047

29. Deng, M., Han, J., Liu, H., Qin, M., Liang, X. Analysis of Compressive Toughness and Deformability of High Ductile Fiber Reinforced Concrete Advances in Materials Science and Engineering 2015, Article ID 384902, 7 pages. http://dx.doi.org/10.1155/2015/384902 